\title{
Outdoor Learning: Fostering Social Awareness with Community Service
}

\author{
Shandy Matitaputty ${ }^{1, *}$, Rini Hastuti ${ }^{1}$, Agnes Christie $^{1}$, and Ika Rahutami $^{2}$ \\ ${ }^{1}$ Taxation Department, Faculty of Economics and Business, Soegijapranata Catholic University, \\ Jl. Pawiyatan Luhur IV No.1, Bendan Dhuwur, Tinjomoyo, Semarang 50235, Indonesia \\ ${ }^{2}$ Management Department, Faculty of Economics and Business, Soegijapranata Catholic University, \\ Semarang 50235, Indonesia
}

\begin{abstract}
This article was motivated by the importance of experiences to foster social awareness. The aim of the study is to proceed an outdoor learning model in developing character, and nationalism insight of students. The model was held in the form of service to the poor and street children. It was expected to create learning climate that touched the hearts of students and to raise compassionate attitude. Using research and development approach, the method was divided into descriptive, evaluative, and experimental methods. Descriptive method was used to collect existing data. Evaluative method was used to evaluate development model of learning outside the classroom; while experimental method was also to test the effectiveness of the model. Subjects in this study were students registered in Indonesian Economy course of Faculty of Economics and Business, SCU Indonesia. This article consists of three stages of analysis, i.e. analysis of the potential economic and social issues surrounding community, student characteristic analysis, and analysis of curriculum and syllabus of Indonesian Economy course to be fit with the concept of outdoor learning. An outline of results showed that the learning model was effectively proven to foster a sense of social awareness and nationalism insight in the college.
\end{abstract}

Keywords: Development, national awareness, research, social awareness,.

\section{Introduction and background}

This article was motivated by the importance of experiences to foster social awareness. Social awareness, according to some sources is defined as a person's ability to understand the condition of others in detail at a specific time, for example, what they do, their emotional state, as well as the environmental conditions around them at the time $[1,2]$. In a broader scope, social awareness also means that a person's consciousness will be viewed by its contribution to the community, environment, or to the nation [2]. Therefore, social awareness can be inferred as an individual's awareness of the existence and involvement in the social environment where it is located.

*Corresponding author: deta.matitaputty@gmail.com 
Indonesian Dictionary (Kamus Besar Bahasa Indonesia-KBBI) defines social awareness as one's full awareness of rights and duties as a member of society [3]. This means that a person with no social consciousness will find difficulties to understand his/her rights and obligations in social life. A person without social awareness will become a man who tends to be less understanding, either less contributing with social environment where he lives.

A person's awareness of rights and duties must be nurtured in the life of society, so as to grow a better, safe, secure and prosperous life [4]. Social awareness serves people to realize that human beings are social beings, being aware of the prevailing norms in society, awakening human beings to create balance, harmonizing social life, getting to know people's status and role, giving views of attitude to overcome social problems [2, 4]. Being competence in the field of social awareness positively influence mental health, success in work, and the ability to be a citizen in a democracy [5].

Awareness of responsibility for the social environment will be arisen when a person has a good understanding of current conditions. A good understanding of the condition of other people, environment, society, and of the nation was formed and enhanced by information received either directly or indirectly. The information that is able to set a proper understanding is the kind of information that is complete and verifiable truth. Obtained information directly shapes individual's understanding. This is because when a person directly contacts or engages with the source of information, he will obtain a complete data and can feel the direct and real situation that is happening. To process the information that has been received into a deep understanding, it requires media called education. This is as Martin Luther King Jr. says, "The function of education is to teach one to think intensely and to think critically." Intelligence plus character-that is the goal of true education" [6].

Education is believed to be a way to improve the quality of human beings. Educated people are considered capable of assessing and addressing a more thoughtful and comprehensive condition. Educated people are also considered to be able to find or create solutions to any problems that are faced. The magnitude of the effect or benefit of acquired education is largely determined by the quality of education itself.

Education involves various elements that are integrated into one. UNICEF states that quality of education is supported by quality of the learners, learning environments, content, processes, and quality of outcomes [7]. It means that the result of education is not solely derived from lecturers/teachers as the sole source of information. Academic skill and intelligent are not best predictor of adult adaption, but the ability to get along with others [5]. Quality of learners is strongly influenced by the subjective condition of the learner. This is because every learner has their own family background, upbringing, as well as the different intellectual abilities. Considering this condition, the lecturer (through formal education) cannot solely determine full quality of the learner because of their varied backgrounds have already been set up to the learners long before they enter the formal education. Outcome is determined by other elements (quality of learners, quality of learning environments, quality of content, and quality of processes); meanwhile three other elements (quality of learning environments, quality of content, and quality of processes) can be designed by lecturers through methods/learning models. Selection of learning model needs to take into account learner, existing and potential environment, and purpose of learning itself.

Some previous researches reveal that social awareness education is important for students. Mallouh Mufdi Barakat Slaihate in Al-asad [8] stated "developing social awareness for youth is seen as an urgent and necessary need, especially, in light of their life's deterioration and their neutrality towards society's issues". Moreover, increasing social awareness of students will improve their critical thinking skills, and will encourage social change. Students who have lack of sense of social awareness are feared, they tend to 
be skeptical students and have a low sense of nationalism. Students who are smart but low in nationalism could be a threat to the life of the nation.

Greeny and Mark [9] stated in their paper about enhancing social awareness development through interaction with diverse peer. The study included 3496 students as sample. There were several findings, the two related results were cognitive/knowledge variable influence students' social awareness; meanwhile college experience variable is controlling variable in social awareness development.

\section{Learning and outdoor learning}

There is no single definition of learning. There are various opinions about the definition of learning, which can be grouped into three major theories, namely behaviorist theory, cognitivist, and constructivist theory. Each theory of learning has its own characteristics and emphasis. Basically, learning involves lecturer, students, and interaction of both through selected learning method.

Table 1. Learning theory table [10].

\begin{tabular}{|l|l|l|l|}
\hline & BEHAVIOURIST & COGNITIVIST & CONSTRUCTIVIST \\
\hline Knowledge is: & $\begin{array}{l}\text { Passive response, } \\
\text { mostly automatic } \\
\text { against external factors } \\
\text { in the environment }\end{array}$ & $\begin{array}{l}\text { Abstract symbolic } \\
\text { representation in } \\
\text { individual minds }\end{array}$ & $\begin{array}{l}\text { Entities are built by each } \\
\text { individual through } \\
\text { learning process. }\end{array}$ \\
\hline Learning is: & $\begin{array}{l}\text { Permanent changes in } \\
\text { behavior }\end{array}$ & $\begin{array}{l}\text { Changes in learners' } \\
\text { understanding }\end{array}$ & $\begin{array}{l}\text { Discovery and } \\
\text { Construction of meaning }\end{array}$ \\
\hline $\begin{array}{l}\text { The focus of } \\
\text { Learning }\end{array}$ & $\begin{array}{l}\text { Association, behavior, } \\
\text { conditioning }\end{array}$ & $\begin{array}{l}\text { Improved meanings } \\
\text { and increased ability to } \\
\text { memorize }\end{array}$ & $\begin{array}{l}\text { Problem solution } \\
\text { and construction of } \\
\text { meaning }\end{array}$ \\
\hline $\begin{array}{l}\text { Key Learning } \\
\text { Concepts }\end{array}$ & $\begin{array}{l}\text { Reinforcement and } \\
\text { learning } \\
\text { Program }\end{array}$ & Elaboration & Intrinsic motivation \\
\hline Focus on: & Lecturer & Students & Students \\
\hline
\end{tabular}

Broderick and Blewitt in Huitt [5] clasified foundational social competencies: (i) affective processes (empathy, giving value of relationships, and sense of belonging), (ii) cognitive processes (cognitive ability, perspective taking, and making moral judgments), (iii) social skills (making eye contact, using appropriate language, and asking appropriate questions), and (iv) high social self-concept.

Epistemological theory of social constructivism stated that human thinking is formed by social interaction and conversation. Theory of Constructivism emphasizes the importance of teacher understanding of students' knowledge and how students can incorporate their knowledge into practice. Roya Jafari Amineh and Hanieh Davatgari Asl [11] In particular research on Constructivism, based on the results of their research, they suggest that with the importance given to collaboration, knowledge, and creativity through both social constructivism and constructivism; the learners can start learning in pair work, group work, and teamwork, and later make the ir own contributions to the world of knowledge.

The use of learning outside the classroom (outdoor learning) will help students to see through, to listen to, to touch, and to learn directly through experiences and conditions that are happening around them. Nugroho et al. [12] stated that outdoor learning is a learning 
process that invites learners to learn outside the classroom and see events directly in the field with the aim is to bring the students closer to their surroundings.

When students observe and experience the real condition around them, students will gain more thorough study than when they learn only in the classroom. The objectives of outdoor learning are: smarter, healthier, safer and stronger, greener, wealthier and fairer [13]. This article suggests a model of learning outside the classroom to develop character and nationalism insight to students. The expected of main character and attitude of nationalism is the attitude of social awareness. The young generation (especially the educated one) who has high social awareness is believed to bring positive impacts to the nation's development.

Outdoor learning provides more attractive learning environment to the students. The essence of learning becomes more meaningful because the students are faced with a situation that is real and natural. Instructional materials are becoming richer and students will be more active to express their ideas and actively contribute to the meeting. Outdoor learning does not merely happen in natural environment where participants can see through, listen to, touch, and smell the real things. It also happens in the arena where action has real results and consequences. Outdoor learning helps develop the skills of enquiry, critical thinking and reflection necessary for children and young people to meet the social, economic and environmental challenges of life $[13,14]$

\section{Methodologies}

\subsection{Educational research and development approach}

Method of research and development in this article is adopted from Borg and Gall [15]. Borg and Gall formulated "Educational Research and Development is a process used to develop and validate educational products". Educational product that is developed through this research and development approach is an outdoor learning. The methodology was subsequently divided into descriptive method, evaluative methods and experimental methods.

Descriptive research method was used in a pilot study to collect data about existing conditions. This method was used at first stage to prepare the outdoor learning. Evaluative method was then used to evaluate development process of learning outside the classroom. This method was run along during and once the outdoor learning had been implemented. That was to evaluate the product in the process of developing outdoor learning. The analysis included the evaluation of results and implementation of the outdoor learning. The evaluation aims to control the learning process and take corrective action needed once it was found deficiencies and constraints. Experimental method was subsequently used to test the effectiveness of the methods that had just been implemented and evaluated. This method was intended to compare between the unevaluated and evaluated group of students who practiced outdoor learning.

Subjects in this study were students who were registered to Indonesian Economy class in the Faculty of Economics and Business, Soegijapranata Catholic University Indonesia in the late of 2016. Indonesia Economy is a subject to be considered because of it discusses socio-economic of the nation. It describes daily conditions in term of economic condition of the people and of the nation. 


\section{Practical implementations}

\subsection{First stage-the preparation for the outdoor learning}

As mentioned above, it is possible to develop a sense of social and nationalism awareness of students by doing outdoor learning. The first step was to collect data of economic and social issues in surrounding community. The data could be obtained and collected from the news, available statistical data that can be easily accessed, as well as social events that were occurred every day around us. Data collection was executed by the students in accordance with the instruction of lecturer. In this stage, students were expected to obtain variety of knowledge and information of economic and social conditions that were happening.

Data about economic and social conditions that had been gathered then being grouped and selected according to the needs of learning objectives. Grouped and selected data were then brought to the lecturers. The selected data will be used for instructional practice sheet. Economic and social conditions were selected as topics for learning practice field. The chosen topics were considered to strengthen the understanding, as well as developing a sense of empathy, critical thinking skills and awareness of social responsibility of students. In this article the chosen sub-topics for instructional practice field in the form of outdoor learning is poverty and children.

Topic of poverty and children had been determined because number of poor people was still quite high and there were many street children to be victims of poverty. The poverty and street children were kind of issues that were closed with the daily life of students. They could see or find it near their lives. It allowed students to interact, learn and contribute directly to the poor society, children from poor families, and also street children.

\subsection{Second stage-learning process and evaluation}

The second stage was the analysis of the student characteristic, students grouping, learning assignment and evaluation. Students were divided into groups for the implementation of the outdoor learning based on their characteristics. Each group consisted of several students that were set up by the lecturer who intensively and individually recognized the students. It was expected each group could cooperate well. With a good cooperation then the learning process will be conducive so as to facilitate the process and goals to be addressed can be achieved, if the cooperation between students is not intertwined then the learning process will be biased with the problems among students themselves that may appear. It was highly required for the lecturer to have good students' characteristics understanding. This lecture's student characteristics understanding should had been developed since the beginning of the course by class observation and interaction. It was expected students could go richer and deeper in their discussion.

After students grouping, the groups were asked to observe and to have direct interaction with the referred poor society. Each group would visit some places that had already been coordinated beforehand by the lecturer. Some of these places were shelters that would be used for class tutoring; some of them were also children playground for poor families and street children. The first place was located in a middle of Semarang city called "Tugu Muda City Park". The park is located on Pemuda Street, Semarang. At this place, there are events held by Emas Indonesia Foundation in every week. The activities cover studying, learning, and playing together with street children. The students were instructed to collaborate with the foundation when the activities were running. The second place was a place where poor 
societies live. It was located on Wonodri, Semarang. After implementation of learning task, an evaluation is conducted to control the learning process and to take corrective actions as quick as finding shortcomings and obstacles. Other lessons that can be gained from activities in these two locations are so that students can understand the behavior of children whom they accompany with either academically and non-academically, either at their home and at the street. So that observation becomes an intact observation, not only seen from one side of the children's lives on the streets alone but also the impacts or obstacles that children experience in their academic education.

\subsection{Third stage-experimental and curriculum development}

At this stage, the effectiveness of outdoor learning methods that had just been implemented was evaluated. It was intended to compare groups of students between unevaluated and evaluated ones. This was a form of improvement and development of learning.

Students observed directly and got engage in activities with poor and street children. Students made interactions with street children, poor families, and children from poor families. Students collected data and information directly to the situation faced by street children, poor families and their children, opinion/their mindset related to several things and their planning in terms of education, health and finance. The collected data such as jobs, living condition, food they eat, family finance management, health, relationships with the people around them (neighborhood), how long they live in such conditions today, whether they accept the poverty alleviation programs of the government, what programs of poverty alleviation they receive, and whether they experience difficulties caused by the economic system, social, political force when they access jobs, education and health services. This information was collected to identify whether these communities experiencing individual or structural poverty.

Information collected by the students about the mindset of street children, poor families and their children i.e. their opinion about the importance of education plans, savings, clean healthy lifestyle, family planning, as well as their views on the role of government and society. This was done to explore the mindset of street children, poor families and their children. Students also collected information from street children, poor families and their children related to their planning in terms of education, health and finance. This information was collected to determine whether these communities had a will to get out of their current condition or not.

Besides assigned to collect information and establish relationships, students were also given a special assignment. A specific assignment that had to be done by the students regarding the conduct of outdoor learning was held in the form of service to the poor and street children. With the educational background of students, students are expected to utilize the knowledge they have to help the community directly through the street children. At least with the process of identifying the problems facing street children thoroughly students should be able to slightly solve existing problems with the provision of knowledge they have gained, both in terms of education, economics, and health. Service to the poor and street children could be given in several forms, including teaching street children and children from poor families meanwhile motivating them to have future goals so that they could have better future.

When students did activities with the children and families of these children, students were trained to empathize, having the ability to listen, and the ability to motivate or share insights and encouragement to the children and families they met. Students then analyzed, compared with the theory that they had received in the classroom and to conclude the causes, indicators and types of poverty suffered by children and communities that they 
visited. Students were also trying to formulate poverty reduction strategies based on the results of their observations and group discussions.

The learning model as it sought to provide a holistic education. This method aimed to touch the brain and heart of students. By interacting and serve directly, lessons were expected to sharpen the knowledge, the ability to analyze and shape the character and attitude of the heart that appropriate to the learning objectives.

The next stage was analysis of curriculum and course syllabus of Indonesian Economy to be fit with the concept of outdoor learning. The review of curriculum and syllabus were continuously developed to find a model of lectures that was more effective, and more in line with the learning objectives to build student's character of nationalism. The curriculum and syllabus are also intended to make the learning model of the students can be continued by the accompanist of street children, so that the assistance given to the street children not only stop at the experimental process done by the students during the learning outside the classroom but can be done sustainable, so that indirectly can help increase national development through education one of them.

\section{Discussions}

Basically, learning is not just a process of knowledge enhancement. The learning process should also result in a relatively permanent change in a person's behavior based on his or her learning experience or process. Learning at this level is characterized by the learner's ability to interpret reality he is facing, judging, and taking action/ decisions. This is important because education should make a person to better understand his role in society and to improve humanity.

Various researches on learning find that the best learning process occurs when students engage in active learning - when they do something instead of neither passively sitting nor listening. Outdoor learning is a learning that is able to make students active directly on the identification process so that learning becomes meaningful and the main concept cognitive learning can be empowered. Outside school environment can be used as a learning resource that is factual, because the learning materials that learners learn in the classroom can be found in the society.

Even though there are many advantages, outdoor learning method with service learning model still has many obstacles. These constraints are grouped into internal and external barriers. Internal barriers arise from individual constraints of students and lecturers. Students may think that the method is new and have no previous knowledge/experience. Some students may feel scared or less confidence. While internal barriers derived from lecturers are related to the capacity to assist a large number of students. Another internal barrier of lecturers is the need for a very good understanding of students' characteristics to compose right groups with matched members. Lecturers are also required to find appropriate location for the implementation of outdoor learning and service learning.

External obstacles for students and lecturer are related to natural factors, transportation and time. The outdoor learning model with service learning method selects locations and groups according to learning topic and observation result. Another constrain came on the way caused by the less favorable weather factor. Schedule had to be adjusted with the assisted group therefore the activities should be implemented out of working hours. Some students who did not have personal transportation could be hampered in their mobility; otherwise they arrange for group transportation.

Apart from those existing barriers, the implementation of outdoor learning combined with service learning methods has broadened the students' personal horizons through greater appreciation and understanding of the world and the communities around them. This can be seen from the enthusiasm of students in generating new ideas as well as their 
feelings when asked to write a reflection on the values of what they get from the activity. In the reflection is read that there is a change in behavior and perspective that so far they do not know. Interesting new experience that there is another side that needs to get attention and the ability of students to do something for their fellowman or society even though they are still in the process of learning.

\section{Results}

An outline of the research results show that the learning model proved effective to foster a sense of social awareness and insight into the nationalism of campus life. Prior to the execution of outdoor learning, student discussions were limited to in-depth theories. Few students actively debate or ask questions about course topics. After interacting with the community in outdoor learning, students can discuss richer and deeper. Students become more diligent in understanding the theories that have been delivered because they are natural to themselves. Their point of view in addressing a problem or a case in the learning process becomes more widespread and critical, not only limited to the theory they obtain but also from other related factors or related factors or related impacts, so that the decision is made more creative and more visionary. All students actively disclose and express their opinions and criticize the theories they have learned. Students can know that the responsibility for poverty alleviation is not solely to the government but also to society as a whole, even including those who are still students or students.

Outdoor learning activities have been shown to improve students' social awareness. Students claim that they find the world as a class, as a learning process that they cannot acquire theoretically but can be found in real life around with various sources of view. Students reveal that they become more grateful for their lives. They are also grateful to be able to interact with the poor and street children directly. Some students are committed to continue to contribute to the activities of Yayasan Emas Indonesia, by helping street children in learning activities. It shows that their sensitivity and concern are sharpened through direct learning process in the field.

\section{Conclusion}

Some previous research reveal that social awareness education is important for students to improve their critical thinking skills, and to encourage social change as well. The aim of the study is to proceed an outdoor learning model in developing character, and nationalism insight of students. The first stage was to collect data of economic and social issues in surrounding community. Topic of poverty and children had been determined because number of poor people was still quite high and there were many street children to be victims of poverty. The second stage was the analysis of the student characteristic, students grouping, learning assignment and evaluation. Students can understand the behavior of children whom they accompany with either academically and non-academically, either at their home and at the street. In the third stage, the effectiveness of outdoor learning methods that had just been implemented was evaluated. Students taught street children and children from poor families, and at the same time motivating them to have future goals. Students were trained to empathize, to have ability to listen, and ability to motivate or share insights and encouragement to the children and families they had met. Students then analyzed the poverty and tried to formulate poverty reduction strategies based on the results of their observations and group discussions. 
The best learning process occurs when students engage in active learning-when they do something instead of neither passively sitting nor listening. Outdoor learning is a learning that is able to make students active directly on the identification process so that learning becomes meaningful and the main concept cognitive learning can be empowered. An outline of the research results show that the learning model proved effective to foster a sense of social awareness and insight into the nationalism. After interacting with the community in outdoor learning, students can discuss richer and deeper. Students become more diligent in understanding the theories; their point of view in addressing a problem or a case in the learning process becomes more widespread and critical, not only limited to the theory they obtain but also from other related factors or related factors or related impacts, so that the decision is made more creative and more visionary. All students actively disclose and express their opinions and criticize the theories they have learned. Students understand that the responsibility for poverty alleviation is not solely to the government but also to society as a whole, including students.

Outdoor learning activities have been shown to improve students' social awareness. Students claim that they find the world as a class, as a learning process that they cannot acquire theoretically but can be found in real life around with various sources of view. Students reveal that they become more grateful for their lives. They are also grateful to be able to interact with the poor and street children directly. Some students are committed to continue to contribute to the activities; it shows that their sensitivity and concern are sharpened through direct learning process in the field.

\section{References}

1. D. D’Amore. TCNJ Journal Of Student Scholarship, X:1-9(2008). https://joss.pages.tcnj.edu/files/2012/04/2008-Damore.pdf

2. S. Ovidiu. Social awareness support for cooperation design experience and theoretical models. [Thesis PhD.]. Royal Institute of Technology, Stockholm, Sweden (2010). p.194.

https://books.google.co.id/books? id=oUZUoJDTMeAC\&printsec=frontcover\&hl=

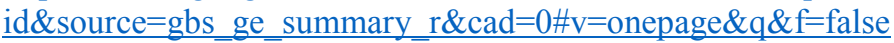

3. S. Dendy (Ed). Kamus Bahasa Indonesia. 4 Ed. [Indonesian dictionary]. Jakarta, Indonesia: Pusat Bahasa (2008). p. 1826. [in Bahasa Indonesia]. https://jurnaloldi.or.id/public/kbbi.pdf

4. B.M. Newman, P.R. Newman. Development through life. 12 ed. USA: Cengage learning (2014). p. 645. https://www.directtextbook.com/isbn/9781285459967

5. W. Huitt, C. Dawson. Social development: Why it is important and how to impact it. [Online] from http://www.edpsycinteractive.org/papers/socdev.pdf (2011). [Acessed on 18 October 2017].

6. M.W. Berkowitz, P. Simmons. The role of moral reasoning on socioscientific issues and discourse. In: Science education. D.L Zeidler (Ed). Netherlands:

Kluwer Academic Publisher (2003). p. 117-138.

https://www.researchgate.net/profile/Dana_Zeidler/publication/318306792 The R ole of Moral Reasoning and Discourse in Science_Education/links/5961adac4 58515a3572b1c1b/The-Role-of-Moral-Reasoning-and-Discourse-in-ScienceEducation.pdf\#page $=119$

7. UNICEF. Defining quality education. Paper presented at the meeting of The International Working Group on Education Florence (Italy, 2000). https://www.unicef.org/education/files/QualityEducation.PDF

8. M.M.B. Slaihate. International Journal of Education, 6,4:71-92(2014). http://dx.doi.org/10.5296/ije.v6i4.6744 
9. R. Shirley, K. Mark. Ties that bind: Enhanced social awareness development through interactions with diverse peers. Paper presented at the Annual Meeting of the Association for the Study of Higher Education (Portland, Oregon, 2003). http://citeseerx.ist.psu.edu/viewdoc/download?doi=10.1.1.590.441\&rep=rep1\&typ $\underline{\mathrm{e}=\mathrm{pdf}}$

10. P.A. Ertmer, T.J. Newby. PIQ, 26,2:43-71(2013)

https://www.uwplatt.edu/files/ttc/idarticle.pdf

11. R.J. Amineh, H. Davatgari. Journal Social Sciences, Literature and Language, 1,1:9-16(2015).

https://pdfs.semanticscholar.org/3890/3f4a7255496f75124d639e14e9b810c17370. pdf

12. A.A. Nugroho, N.R. Hanik. Bioedukasi, 56: 41-44 (2016). [in Bahasa Indonesia]. http://jurnal.fkip.uns.ac.id/index.php/biologi/article/view/9067

13. K. Brown. Curriculum for excellence through outdoor learning. UK: Learning and Teaching Scotland (2010). p. 28. https://education.gov.scot/Documents/cfethrough-outdoor-learning.pdf

14. Y.A. Plant, Addysg, D.G.O. a Sgiliau. Foundation phase outdoor learning handbook. UK: Welsh assembly government (2009). p. 24. http://learning.gov.wales/docs/learningwales/publications/140828-foundationphase-outdoor-learning-handbook-en.pdf

15. K. Klette. The role of theory in educational research. Norwegian Educational Research Toward 2020-UTDANNING 2020, (Oslo, USA 2012) p. 3. https://www.forskningsradet.no/servlet/Satellite?cid=1253979441594\&pagename =VedleggPointer\&target $=$ blank 